\title{
The Effect of Blends between Some Egyptian cotton Varieties and Introduced Cottons on Technological and Spinning Characters
}

\author{
Shereen A. Esmail ${ }^{1}$, Sami Sh. EL-Tabbakh ${ }^{2}$, Ali I. Nawar ${ }^{2}$ and Mahmoud I. EL-Bagoury ${ }^{1}$
}

\begin{abstract}
Two Egyptian long staple cotton varieties (Giza 86 and Giza 80) were blended with imported Greek and Russian cottons at 100, 75, 50, 25 and 0 percent of Egyptian cotton component in blend. The objective of the study was to determine the effect of blending, with different percentages, on fiber and yarn properties. The study was set up as split plot design, where the varietal blends were allocated to the main plots and the blending percentages assigned to the subplots.
\end{abstract}

Fiber properties, i.e., fiber length, uniformity and fiber strength values decreased, whereas fiber elongation, mirconaire value and neps count increased, with increasing imported upland cotton percentage in the blend. Differences were also found between Egyptian cotton cultivars where Giza 86 gave higher values for fiber length and strength values, but lower micronaire and neps values compared to Giza 80.

Concerning yarn characteristics, most of the studied yarn properties were not affected by varietal blends, blending percentages and their interaction. However, number of neps places were lower for introduced cotton compared to Egyptian cotton. Yarn elongation varied significantly with the percentage of imported cotton in the blend and was highest (5.94) with 50:50\% Egyptian to introduced cotton.

The correlation between blended fiber properties and yarn characteristics varied according to varietal blend, but, generally, showed negative correlation between single yarn strength and fiber micronaire value $(-0.54)$, and between yarn uniformity and blended fiber elongation (0.58).

Keywords: Cotton blends, yarn properties, fiber properties, blending percentage.

\section{INTRODUCTION}

The cotton industry in Egypt during the last decade suffered major reduction in both area allocated for cotton cultivation and total exported quantities, and that was accompanied by an increase in imported upland cottons (E.C.G, 2015 and CATGO, 2016). Several reasons contributed to the difficulties facing the cotton industry in Egypt including increase in production expenses, deterioration of cultivated varieties in yield and quality and lower demand for Egyptian cotton in international markets due to its higher prices compared to other cottons of nearly similar quality properties (CATGO, 2008 and E.C.G, 2015).

Imported upland cottons are of inferior fiber quality characteristics compared to Egyptian cotton. Hence blending between the two categories of cotton lint may offer an opportunity to obtain yarns with higher quality than that of upland cotton and of lower prices (Hsien et $a l ., 2000)$. However, blending of cottons with different quality characteristics may have an effect on fiber characteristics of the blend and resulting yarn quality (Majumdar, 2004 and Nomer and Abd El-Hamid, 2005). Ureyen and Kadoglu (2006) reported that cotton yarn properties were significantly affected by fiber properties such as strength, elongation and fineness, and to a lesser extent by uniformity, length and short fibers content.

Similarly, Faulkner et al. (2012) found that yarn properties were most frequently correlated to fiber length, strength and fineness. Cai et al. (2013) stressed the importance of fiber length as a key property for yarn production and quality.

The present study was carried out to investigate the blending of two Egyptian long staple cotton cultivars (Giza 86 and Giza 80) with imported upland cotton from Greece and Russia, on fiber quality and properties of yarn.

\section{MATERIALS AND METHODS}

The present investigation was carried out during 2010 and 2011 to study the effect of blending two long staple Egyptian cotton (Gossypium barbadense) cultivars (Giza 86 and Giza 80) with introduced upland cotton (Gossypium hirsutum) from Greece and Russia.

Blending percentages were 0, 25, 50, 75 and $100 \%$ introduced upland cotton in blend. Egyptian cotton cultivars were grown at the Agricultural Research Station, Alexandria University during the summer seasons of 2010 and 2011. Seed cotton was ginned and the resulting lint was adjusted to grade Good by an expert committee from CATGO (Cotton Arbitration and Testing General Organization). Introduced Cotton was supplied by Cotton Exporters Federation. Blending was performed by the Sandwich blending technique based

${ }^{1}$ Cotton Arbitration and Testing General Organization,

Alexandria, Egypt.

${ }^{2}$ Crop Science Dept., Fac. of Agriculture, Alexandria University,

Alexandria, Egypt.

Received January 29, 2017, Accepted February 5, 2017 
on the standard method designated by the A.S.T.M (1984) standards (D-1441).

The fiber properties of blends were measured by H.V.I (High Volume Instrument) model 1000. These included fiber length (as upper half mean, UHM), uniformity percentage (UI), fiber strength (FS), fiber elongation (FE), fiber fineness (micronaire value, MIC) and neps count $(\mathrm{N})$. Varietal blends were then spun at the spinning laboratory of "Cotton Arbitration and Testing General Organization" Smouha, Alexandria. The skein test was made according to A.S.T.M. Designation (D - 1578) using the Good Brand Lea Tester. Lea product was estimated by spinning lint cotton into carded yarns with count 60 and 3.6 twist factor. Yarn tests were carried out at "Textile Consolidation Fund (Elsyouf) Alexandria.

Yarn quality characters measured included Yarn evenness (YU), Number of neps places/1000 meter (YN), Break factor (BF), Single yarn strength (R.K.M) and Yarn elongation (YE).

Data were statistically analyzed as split-plot design with three replications using SAS (Statistical Analysis System) version 8.1 (2000), according to the procedure proposed by Gomez and Gomez (1984). L.S.D was used for comparing between means of main factors and their interaction at $(5 \%)$ level of probability.

\section{RESULTS AND DISCUSSION}

Analysis of data showed that all studied fiber characteristics were significantly affected by varietal blends, except fiber length expressed as upper half mean (UHM) and fiber elongation, blending percentages and the two factor interaction (Table 1). The data revealed that imported upland cottons, i.e. Greek or Russian, had inferior fiber characteristics compared to Egyptian cultivars, where they gave lower fiber length, uniformity and fiber strength values, but gave higher elongation, micronaire and neps values. These results were in accordance with those reported by several investigations (EL-Bagoury, 1992 and Nomeir and Abd EL-Hameed, 2005) who found that blending of Egyptian cotton with upland cottons, or even lower grades of Egyptian cotton, significantly reduced fiber properties of the blend. Characteristics of varietal blends was primarily influenced by the properties of Egyptian cultivar where blends with Giza 86 gave higher fiber strength values and lower micronaire and neps compared to the blends with Giza 80 , and that could be attributed to the better fiber quality properties of Giza 86 compared to Giza 80.

Concerning blending percentages, the results presented in (Table 1) clearly showed that increasing the percentage of introduced cotton in the blend led to a significant and gradual decrease in fiber properties. The data indicated that fiber length, uniformity and strength significantly decreased, while fiber elongation, micronaire value and neps count significantly increased with increasing the upland cotton component in the belnd. However, fiber elongation showed statistically similar values for $75: 25 \%$ and $50: 50 \%$ blends to $100 \%$ Egyptian cotton. Similar findings were reported by Shalaby (1985) and Samra and Ashour (1987) who found that blends of Egyptian cotton cultivars with imported upland cottons of different sources and percentages, led to deterioration of quality characteristics of fibers, such as fiber length, fiber bundle strength and micronaire reading. They explained that by the lower maturity of introduced cottons compared to Egyptian cotton, which was confirmed, also, by the findings of Nomeir and Abd El-Hameed (2005).

Concerning yarn characteristics, most of the studied properties of yarn were not affected by varietal blends, blending percentages or their interaction (Table 2). However, number of neps places were lower for imported cotton compared to Egyptian cotton. That may be explained by the observed trash content (not included) which was higher in Egyptian cotton compared to pneumatically -cleaned imported upland cotton. Moreover, yarn elongation varied significantly with the percentage of imported cotton in the blend and was highest (5.94) with 50:50\% Egyptian to importeded cotton.

The varietal blend $\mathrm{x}$ blending percentage interaction showed significant variation only in yarn elongation, where the highest value was obtained with 50:50\% blending of Giza 80 and Russian cotton, whereas the lowest value was obtained, at the same blending percentage, for Giza 86 and Greek cotton blend. That indicates the lower fiber maturity of imported Russian cotton compared to that of imported Greek cotton. Ozcelik and Kirtay (2006) reported the Greek cotton was of suitable maturity ratio for enhancing yarn elongation property.

The correlation between blended fiber properties and yarn characteristics (Table 3, a, b,c and d) showed variable outcomes according to the varietal blend. In Giza 86 x Greek cotton blend, yarn elongation was positively and significantly correlated with blended fiber uniformity index (0.60). In Giza 86 x Russian cotton blend, yarn evenness was negatively and significantly correlated with blended fiber elongation (0.58 ) and, similarly, single yarn strength was negatively and significantly correlated with fiber micronaire value $(-0.54)$, indicating the lower maturity of blended fibers. In Giza 80x Greek cotton blend, yarn elongation was positively and significantly correlated with fiber 
strength (0.63) whereas yarn evenness was negatively and significantly correlated with blended fiber length ($0.64)$ indicating the higher short fibers in Greek cotton leading to a higher variation in number of thin and thick places of the resulting yarn.

The fourth varietal blend, i.e. Giza 80 x Russian cotton showed insignificant relationship between studied fiber and yarn properties of blend. Several researchers reported the influence of fiber properties on yarn characteristics. Cai et al. (2013) showed that variations in fiber length distributions play an important role in determining yarn properties, such as strength and irregularity. Dever (2013) stated that fiber elongation was a critical character that determines the amount of energy required to break a yarn and is important to processing performance. Similarly, Sharma (2013) reported that several characters such as fiber length, fineness, uniformity, maturity and strength will affect the properties of spun yarn.

Table 1. Effect of varietal blends and blending percentages on fiber properties

\begin{tabular}{|c|c|c|c|c|c|c|c|c|}
\hline \multirow{2}{*}{$\begin{array}{c}\text { Varietal } \\
\text { Blends (VB) }\end{array}$} & \multicolumn{2}{|c|}{$\begin{array}{c}\text { Blending } \\
\text { Percentages (Bp) }\end{array}$} & \multirow{2}{*}{$\begin{array}{l}\text { UHM } \\
(\mathbf{m m})\end{array}$} & \multirow{2}{*}{$\begin{array}{c}\text { UI } \\
(\%)\end{array}$} & \multirow{2}{*}{$\begin{array}{c}\text { FS } \\
(\mathrm{g} / \mathrm{tex})\end{array}$} & \multirow{2}{*}{$\begin{array}{l}\text { FE } \\
(\%)\end{array}$} & \multirow[t]{2}{*}{ MIC } & \multirow[t]{2}{*}{ N/gram } \\
\hline & $\mathbf{E}$ & I & & & & & & \\
\hline \multirow{5}{*}{ G86 $\times$ Greek } & 100 & 0.0 & 33.05 & 88.83 & 45.43 & 5.86 & 3.36 & 62.00 \\
\hline & 75 & 25 & 33.24 & 85.96 & 41.93 & 6.16 & 3.90 & 86.33 \\
\hline & 50 & 50 & 32.47 & 86.03 & 38.63 & 6.16 & 4.04 & 104.33 \\
\hline & 25 & 75 & 31.12 & 85.00 & 38.40 & 6.26 & 4.32 & 126.33 \\
\hline & 0.0 & 100 & 29.83 & 83.26 & 31.96 & 6.36 & 4.31 & 224.66 \\
\hline \multirow{6}{*}{ G86 × Russ } & Mean & & $31.95 \mathrm{a}^{(1)}$ & $85.82 \mathrm{a}$ & $39.27 \mathrm{a}$ & $6.17 \mathrm{a}$ & $3.99 \mathrm{~b}$ & $121 \mathrm{c}$ \\
\hline & 100 & 0.0 & 33.53 & 87.83 & 45.60 & 6.20 & 3.66 & 63.00 \\
\hline & 75 & 25 & 32.60 & 86.70 & 44.86 & 5.95 & 3.81 & 80.33 \\
\hline & 50 & 50 & 31.19 & 85.13 & 42.73 & 6.23 & 3.89 & 112.66 \\
\hline & 25 & 75 & 32.30 & 84.23 & 36.00 & 5.83 & 4.19 & 186.33 \\
\hline & 0.0 & 100 & 29.18 & 82.80 & 31.13 & 6.36 & 4.32 & 261.66 \\
\hline \multirow{6}{*}{ G80×Greek } & Mean & & $31.76 \mathrm{a}$ & $85.34 \mathrm{a}$ & $40.06 \mathrm{a}$ & $6.12 \mathrm{a}$ & $3.98 \mathrm{~b}$ & $141 \mathrm{c}$ \\
\hline & 100 & 0.0 & 32.69 & 86.46 & 38.93 & 5.40 & 4.82 & 80.66 \\
\hline & 75 & 25 & 32.59 & 83.26 & 36.10 & 6.13 & 4.69 & 145033 \\
\hline & 50 & 50 & 32.10 & 85.96 & 37.60 & 6.46 & 4.63 & 155.33 \\
\hline & 25 & 75 & 31.07 & 84.36 & 35.03 & 6.03 & 4.58 & 197.33 \\
\hline & 0.0 & 100 & 29.76 & 83.70 & 33.06 & 6.30 & 4.37 & 249.66 \\
\hline \multirow{6}{*}{ G80× Russ } & Mean & & $31.65 \mathrm{a}$ & $84.75 \mathrm{a}$ & $36.15 b$ & $6.07 \mathrm{a}$ & $4.62 \mathrm{a}$ & $166 \mathrm{~b}$ \\
\hline & 100 & 0.0 & 32.92 & 84.13 & 39.03 & 5.40 & 4.68 & 85.00 \\
\hline & 75 & 25 & 30.67 & 83.83 & 36.83 & 5.36 & 4.67 & 161.66 \\
\hline & 50 & 50 & 31.13 & 83.33 & 36.90 & 5.36 & 4.60 & 198.66 \\
\hline & 25 & 75 & 30.88 & 82.56 & 34.66 & 5.86 & 4.52 & 240.66 \\
\hline & 0.0 & 100 & 29.21 & 82.26 & 31.36 & 6.26 & 4.39 & 276.00 \\
\hline \multirow{6}{*}{$\begin{array}{c}\text { Blending } \\
\text { percentages } \\
(\mathrm{Bp})\end{array}$} & Mean & & $30.97 \mathrm{a}$ & $83.23 \mathrm{~b}$ & $35.76 b$ & $5.64 \mathrm{a}$ & $4.58 \mathrm{a}$ & $192 \mathrm{a}$ \\
\hline & 100 & 0.0 & $33.05 \mathrm{a}$ & $86.82 \mathrm{a}$ & $42.25 \mathrm{a}$ & $5.72 \mathrm{c}$ & $4.13 \mathrm{c}$ & $73 \mathrm{e}$ \\
\hline & 75 & 25 & $32.28 \mathrm{~b}$ & $85.12 \mathrm{~b}$ & $39.93 b$ & $5.91 b c$ & $4.27 \mathrm{~b}$ & $118 \mathrm{~d}$ \\
\hline & 50 & 50 & $31.73 \mathrm{bc}$ & $84.94 \mathrm{~b}$ & $38.97 b$ & $6.00 \mathrm{bc}$ & $4.29 b$ & $143 \mathrm{c}$ \\
\hline & 25 & 75 & $31.35 \mathrm{c}$ & $84.04 b c$ & $36.03 \mathrm{c}$ & $6.04 \mathrm{ab}$ & $4.35 \mathrm{ab}$ & $188 \mathrm{~b}$ \\
\hline & 0.0 & 100 & $29.50 \mathrm{~d}$ & $83.00 \mathrm{c}$ & $31.88 \mathrm{~d}$ & $6.33 \mathrm{a}$ & $4.41 \mathrm{a}$ & $253 \mathrm{a}$ \\
\hline \multicolumn{3}{|c|}{ L.S.D ${ }_{0.05}$ Blending percentage } & 0.69 & 1.15 & 1.42 & 0.31 & 0.10 & 19.07 \\
\hline \multicolumn{3}{|c|}{ L.S.D ${ }_{0.05}$ Varietal blends } & n.s & 1.10 & 2.07 & n.s & 0.23 & 21.84 \\
\hline \multicolumn{3}{|c|}{ L.S.D ${ }_{0.05}(\mathrm{VB} * \mathrm{Bp})$} & 1.72 & 2.72 & 6.21 & 0.30 & 0.80 & 57.79 \\
\hline
\end{tabular}

(1) Means followed by the same letter(s) are insignificantly different at 0.05 level of probability. 
Table 2. Effect of varietal blends and blending percentages on yarn characteristics

\begin{tabular}{|c|c|c|c|c|c|c|c|}
\hline \multirow{2}{*}{$\begin{array}{c}\text { Varietal } \\
\text { Blends (VB) }\end{array}$} & \multicolumn{2}{|c|}{$\begin{array}{c}\text { Blending } \\
\text { Percentages (Bp) }\end{array}$} & \multirow{2}{*}{$\begin{array}{l}\text { YU } \\
(\%)\end{array}$} & \multirow{2}{*}{$\begin{array}{l}\mathrm{YN} / 1000 \\
\text { meter }\end{array}$} & \multirow{2}{*}{$\begin{array}{l}\text { BF } \\
(\mathrm{g})\end{array}$} & \multirow[t]{2}{*}{ RKM } & \multirow{2}{*}{$\begin{array}{l}\text { YE } \\
(\%)\end{array}$} \\
\hline & $\mathbf{E}$ & I & & & & & \\
\hline \multirow{5}{*}{ G86 × Greek } & 100 & 0.0 & 18.36 & 2547.66 & 159.96 & 13.53 & 5.26 \\
\hline & 75 & 25 & 18.43 & 1946.00 & 144.70 & 13.93 & 5.14 \\
\hline & 50 & 50 & 17.96 & 1668.33 & 147.30 & 12.33 & 4.66 \\
\hline & 25 & 75 & 19.26 & 1845.00 & 158.80 & 15.16 & 5.83 \\
\hline & 0.0 & 100 & 18.10 & 1692.33 & 146.60 & 13.16 & 5.46 \\
\hline \multicolumn{3}{|c|}{ Mean } & $18.43 \mathrm{a}^{(1)}$ & $1940 \mathrm{a}$ & $151.47 \mathrm{a}$ & $13.63 \mathrm{a}$ & $5.27 \mathrm{a}$ \\
\hline \multirow{5}{*}{ G86 × Russ } & 100 & 0.0 & 19.10 & 1730.00 & 150.36 & 13.43 & 6.53 \\
\hline & 75 & 25 & 20.40 & 2142.66 & 125.16 & 11.06 & 5.13 \\
\hline & 50 & 50 & 19.93 & 2119.33 & 133.53 & 13.70 & 5.26 \\
\hline & 25 & 75 & 20.10 & 3521.00 & 132.20 & 13.66 & 5.13 \\
\hline & 0.0 & 100 & 19.30 & 1565.33 & 168.26 & 15.26 & 5.16 \\
\hline \multicolumn{3}{|c|}{ Mean } & $19.77 \mathrm{a}$ & $2216 a$ & $141.91 \mathrm{a}$ & $13.43 \mathrm{a}$ & $5.45 \mathrm{a}$ \\
\hline \multirow{5}{*}{ G80 × Greek } & 100 & 0.0 & 17.96 & 2572.66 & 136.20 & 11.80 & 5.26 \\
\hline & 75 & 25 & 17.56 & 1387.33 & 157.60 & 14.33 & 5.90 \\
\hline & 50 & 50 & 17.43 & 1879.00 & 150.50 & 12.10 & 6.33 \\
\hline & 25 & 75 & 18.43 & 2152.33 & 148.83 & 13.90 & 5.10 \\
\hline & 0.0 & 100 & 19.46 & 1998.66 & 139.66 & 12.16 & 5.30 \\
\hline \multicolumn{3}{|c|}{ Mean } & $18.17 \mathrm{a}$ & $1998 \mathrm{a}$ & $146.56 \mathrm{a}$ & $12.86 \mathrm{a}$ & $5.58 \mathrm{a}$ \\
\hline \multirow{5}{*}{ G80 × Russ } & 100 & 0.0 & 18.53 & 2359.00 & 176.33 & 14.16 & 6.23 \\
\hline & 75 & 25 & 18.33 & 2257.00 & 160.46 & 13.16 & 5.53 \\
\hline & 50 & 50 & 18.93 & 2391.33 & 149.56 & 13.96 & 7.50 \\
\hline & 25 & 75 & 19.13 & 2683.00 & 112.66 & 10.90 & 5.43 \\
\hline & 0.0 & 100 & 17.10 & 2022.33 & 162.86 & 13.13 & 4.80 \\
\hline \multicolumn{3}{|c|}{ Mean } & $18.41 \mathrm{a}$ & $2343 \mathrm{a}$ & $152.38 \mathrm{a}$ & $13.27 \mathrm{a}$ & $5.90 \mathrm{a}$ \\
\hline & 100 & 0.0 & $18.49 \mathrm{a}$ & $2302 \mathrm{ab}$ & $155.72 \mathrm{a}$ & $13.23 \mathrm{a}$ & $5.83 \mathrm{ab}$ \\
\hline Blending & 75 & 25 & $18.68 \mathrm{a}$ & $1933 \mathrm{ab}$ & $146.98 \mathrm{a}$ & $13.13 \mathrm{a}$ & $5.42 \mathrm{a} \mathrm{b}$ \\
\hline percentages & 50 & 50 & $18.57 \mathrm{a}$ & $2015 \mathrm{ab}$ & $145.23 \mathrm{a}$ & $13.03 \mathrm{a}$ & $5.94 \mathrm{a}$ \\
\hline \multirow[t]{2}{*}{$(\mathrm{Bp})$} & 25 & 75 & $19.23 \mathrm{a}$ & $2550 \mathrm{a}$ & $138.13 a$ & $13.41 \mathrm{a}$ & $5.38 \mathrm{ab}$ \\
\hline & 0.0 & 100 & $18.49 \mathrm{a}$ & $1820 \mathrm{~b}$ & $154.35 \mathrm{a}$ & $13.68 \mathrm{a}$ & $5.18 \mathrm{~b}$ \\
\hline \multirow{3}{*}{\multicolumn{3}{|c|}{$\begin{array}{l}\text { L.S. } D_{0.05} \text { Blending percentage } \\
\text { L.S.D } D_{0.05} \text { Varietal blends } \\
\text { L.S.D. }{ }_{0.05}\left(V^{*} \text { Bp) }\right.\end{array}$}} & n.s & 627.22 & n.s & n.s & 0.66 \\
\hline & & & n.s & n.s & n.s & n.s & n.s \\
\hline & & & n.s & n.s & n.s & n.s & 2.02 \\
\hline
\end{tabular}

(1) Means followed by the same letter(s) are insignificantly different at 0.05 level of probability.

Table 3. Correlation coefficients between fiber and yarn properties in studied varietal blends overall blending percentages

\begin{tabular}{cccccccccccc}
\hline \multicolumn{1}{c}{ (a) Giza 86 $\times$ Greek cotton } & \multicolumn{4}{c}{ (b) Giza 86 $\times$ Russian cotton } \\
\hline Properties & BF & YE & YU & RKM & YN & Properties & BF & YE & YU & RKM & YN \\
FL & 0.11 & 0.38 & 0.14 & 0.18 & 0.42 & FL & -0.29 & 0.30 & 0.02 & -0.36 & 0.07 \\
FS & 0.12 & 0.48 & 0.06 & 0.08 & 0.41 & FS & -0.37 & 0.30 & 0.04 & -0.39 & 0.12 \\
FE & 0.17 & -0.49 & -0.12 & 0.42 & -0.44 & FE & 0.23 & -0.07 & $-0.58^{*}$ & 0.02 & 0.08 \\
UI & 0.39 & $0.60^{*}$ & -0.19 & 0.17 & 0.13 & UI & -0.06 & 0.12 & -0.15 & -0.26 & -0.09 \\
MIC. & 0.13 & 0.17 & 0.06 & 0.19 & 0.24 & MIC. & -0.53 & 0.25 & 0.06 & $-0.54^{*}$ & 0.06 \\
N & -0.19 & -0.29 & 0.04 & -0.11 & -0.16 & N & 0.33 & -0.29 & -0.009 & 0.34 & -0.09 \\
& & & & & & & & & & \\
\hline
\end{tabular}


$*$,** significant at 0.05 and 0.01 levels of probability, respectively.

\section{REFERENCES}

A.S.T.M. 1984. American Society for Testing and Materials Designation( D-1441).

C.A.T.G.O. 2008. "Cotton Arbitration and Testing General Organization, Publication of the Information and Documentation Center, Cotton Bulletin, $4^{\text {th }}$ Annual Report, July 2008.

C.A.T.G.O. 2016. "Cotton Arbitration and Testing General Organization, Publication of the Information and Documentation Center, Data of Cotton Season 2015/2016. November, 2016 (in Arabic).

Cai, Y., X. Cui, J. Rodgers, D. Thibodeaux, V. Martin, M. Watson and S. Pang. 2013. A comparative study of the effect of cotton fiber length parameters on modeling yarn properties. Textile Research Journal. 83 (9) 961-970.

Dever, J. 2013. Improving fiber elongation of U.S. germplasm. Project of Texas Agrilife Research. Lubbock, Texas . www.cottoninc.com.

E.C.G. 2015. The Egyptian Cotton Gazette, No. 144, April 2015.

EL-Bagoury,M.I. 1992.Technological Evaluation of Blended Different Lint Grades of Some Egyptian Cotton Cultivars . Ph.D. thesis, Faculty of Agriculture (Saba Basha), Alexandria University, Egypt.

Faulkner, W.B., F. H. Eric., W. John, And Randal, B. 2012. Relationships of cotton fiber properties to ring - spun yarn quality on selected high plains cottons. Textile Research Journal 82 (4): 400-414.
Gomez, K.A. and A.A. Gomez.1984. Statistical Procedures for Agricultural Research. $2^{\text {nd }}$ ed. John Wiley and Sons, New York. USA.

Hsien, Y. , X.P. Hu and A. Wang. 2000. Single fiber strength variations of Developing cotton fibers - strength and structure of G.hirsutum and G.barbadense. Textile Research Journal 70 (8): 682-690.

Majumdar, A. 2004. Predicting the Breaking Elongation of ring spun cotton yarns using Mathematical, Statistical, and Artificial Neural Network Models. Textile Research Journal 74 (7): 652- 655.

Nomeir, K.A. and N.M. Abd EL-Hameed. 2005. Report of Quality Control of Cotton Spinning Industry, Textile Consolidation Fund.

Ozcelik. G and E. Kirtay. 2006. Examination of the Influence of selected fibre properties on yarn Peppiness. Fibres and Textiles in Eastern Europe. 14 (3) : 52-57.

Samra, A.M. and A.Y. Ashour. 1987. Blending Egyptian and upland cotton diverse in their physical properties. Agric. Res. Rev., 65: 749 - 759.

Shalaby, A.W. 1985. A study on the effect of blending Egyptian and American cottons on technological properties of fiber and yarn. Ph. D. Thesis, Faculty of Agriculture, Al-Azhar university, Egypt.

Sharma, S. K. 2013. Yarn hairiness. Spinning textile.7 (6).

Ureyen, M.E. and H. Kadoglu. 2006. Regressional estimation of ring spun cotton yarn properties from $\mathrm{H} \mathrm{V} \mathrm{I}$ fiber properties. Textile Research Journal. 76 (5) : 360-366. 


\section{الملذص المري \\ تأثير خلالت بهن الهنه الثمان المصرية والمستورة عل الصفلت التكنولوجية والغزلية}

شيرين عزب لسماعل ؛سلمشعبلن الطباخ؛ على عيسى نوار؛ محمود لسماعل البلجورى

مغطم خواص الغزل بالخط بين الاصنف المصرية والنطن

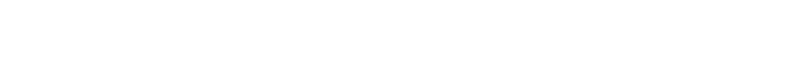

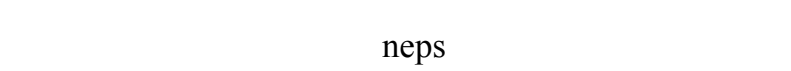

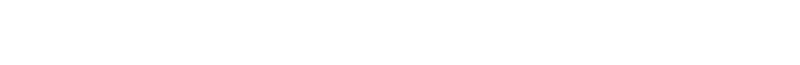

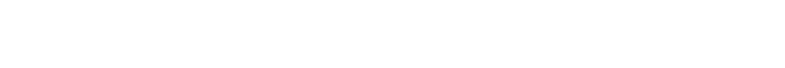

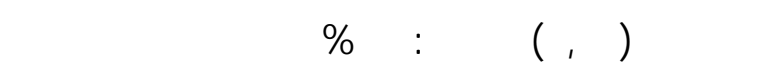
مستورد.

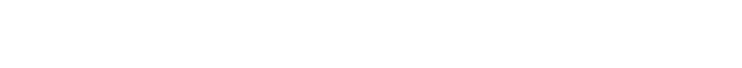

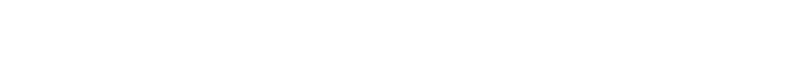
الفطن الامريكى المستورد. لطهرت النتائج ارتبطاس الماس البا

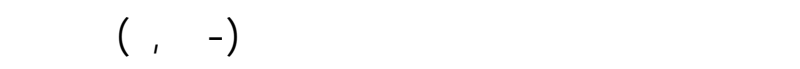
انظلمية الغزل ولسطالة الاليف المخلوطة ( -ON, -).
مق خلط صفلن من التطن المصرى جيزة 17 وجي -زة

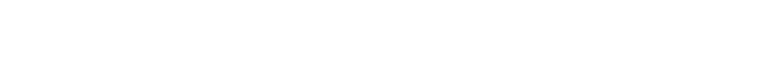

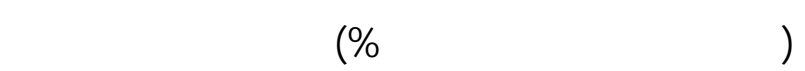

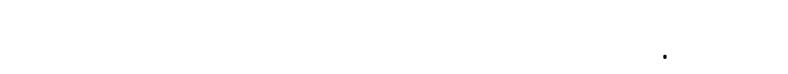

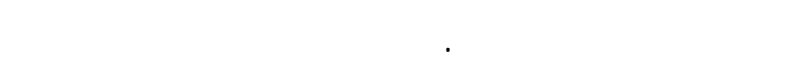

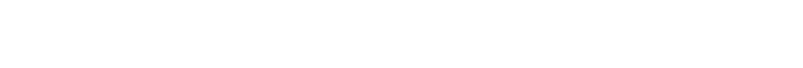

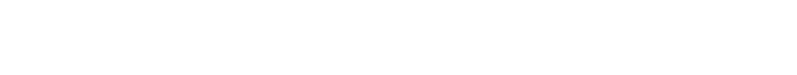
نسب الخطا فى التطع المثقة.

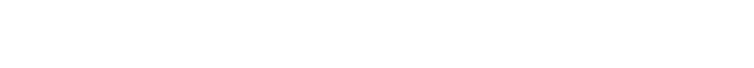
قيم لسطالة التيلة، الميكرونير وneps و ـ بزياة غنب التطن

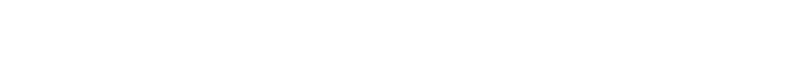

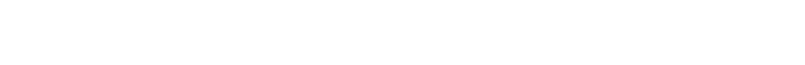

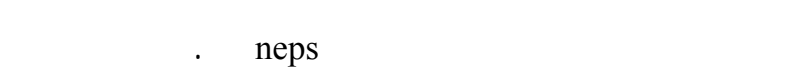

